\title{
Meningkatkan Minat Baca Buku Cerita Dengan Metode Kupas Rangkai Suku Kata Pada Anak Usia 3-4 Tahun: Studi Kasus PAUD Ibu Sadar Dusun Nginjen Desa Pandanpancur Kecamatan Deket Kabupaten Lamongan
}

\author{
Emalia Nova Sustyorini \\ Fakultas ekonomi Universitas Islam Lamongan \\ Email corresponding author: emaliaberlian@gmail.com
}

\begin{abstract}
ABSTRAK
Penelitian ini bertujuan untuk mendeskripsikan: Meningkatkan minat membaca buku cerita dengan metode kupas rangkai suku kata pada anak usia 3-4 tahun di PAUD Ibu sadar Dusun nginjen Desa pandanpancur Kecamatan deket Kabupaten lamongan. Penelitian ini menggunakan rancangan penelitian kualitatif. Objek utama penelitian ini adalah meningkatkan minat membaca buku cerita dengan metode kupas rangkai suku kata pada anak usia 3-4 tahun di PAUD Ibu sadar Dusun nginjen Desa pandanpancur Kecamatan deket Kabupaten Lamongan. Lokasi penelitian ini di PAUD Ibu sadar Dusun nginjen Desa pandanpancur Kecamatan deket Kabupaten Lamongan. Data dalam penelitian ini meningkatkan minat membaca buku cerita dengan metode kupas rangkai suku kata pada anak usia 3-4 tahun di PAUD Ibu sadar Dusun nginjen Desa pandanpancur Kecamatan deket Kabupaten Lamongan. Teknik pengumpulan data yang digunakan adalah teknik observasi, wawancara, dan pencatatan. Teknik yang digunakan adalah teknik analisis deskriptif. Hasil penelitian meningkatkan minat membaca buku cerita dengan metode kupas rangkai suku kata pada anak usia 3-4 tahun di PAUD Ibu sadar Dusun nginjen Desa pandanpancur Kecamatan deket Kabupaten Lamongan yaitu dengan sering mengajak anak untuk melakukan membaca buku cerita minimal sehari 2 kali, memilih tema buku cerita yang disukai anak, dan mengatur waktu dalam membaca.
\end{abstract}

Kata Kunci: Minat, Membaca, Metode kupas rangkai suku kata

\section{PENDAHULUAN}

Membaca merupakan suatu keterampilan berbahasa yang harus dimiliki oleh semua orang. Ada empat keterampilan dalam berbahasa yaitu: membaca, menyimak, menulis, dan berbicara. Membaca merupakan suatu kegiatan yang dilakukan oleh seorang pembaca untuk memperoleh suatu pesan yang akan disampaikan oleh pembaca melalui media lisan atau tulisan. Membaca merupakan memahami dari apa yang ditulis. Membaca adalah proses yang dilakukan serta dipergunakan oleh pembaca untuk memperoleh pesan, yang hendak disampaikan oleh penulis melalui media kata-kata atau bahasa tulis. Suatu proses yang menuntut agar kelompok kata yang merupakan suatu kesatuan akan terlihat dalam suatu pandangan sekilas dan makna kata-kata secara individual akan dapat diketahui. Kalau hal ini tidak terpenuhi, pesan yang tersurat dan yang tersirat tidak akan tertangkap atau 
dipahami, dan proses membaca itu tidak terlaksana dengan baik. (Hodgoson, 1960:43-44). Membaca di sekolah khususnya anak-anak usia 3-4 tahun biasanya diawali dengan tahap membaca permulaan misalnya membaca sebuah buku cerita anak.

Tarigan (1995:5) mendefinisikan bahwa cerita anak adalah buku yang menempatkan mata anak-anak sebagai pengamat utama, mata anak-anak sebagai fokusnya. Bruno Bettheim (2011), menyebutkan bahwa cerita yang menarik untuk anak haruslah merangsang imajinasi, membantu mengembangkan kecerdasan, menjernihkan emosi, dan menyesuaikan diri dengan kecemasan ketika ia dihadapkan pada pencarian jalan keluar. Cerita untuk anak selayaknya berkaitan dengan anak, misalnya saja dongeng-dongeng yang merefleksikan pandangan anak tentang dunia. Pada anak usia 3-4 tahun metode yang digunakan membaca cerita anak salah satunya menggunakan sebuah metode kupas rangkai suku kata.

Metode kupas rangkai suku kata merupakan suatu metode yang memulai pengajaran dengan menyajikan dahulu beberapa suku kata. Suku kata dirangkaikan menjadi kata dengan menggunakan tanda sambung. Suku kata dikupas menjadi huruf-huruf. Huruf-huruf dirangkai kembali menjadi suku kata. Menurut Supriyadi Depdikbud (1992:12) metode kupas rangkai suku kata adalah suatu metode yang memulai pengajaran membaca permulaan dengan menyajikan kata-kata yang sudah di rangkai menjadi suku kata, kemudian suku-suku kata itu di rangkai, yang terakhir merangkai kata menjadi kalimat. Metode kupas rangkai suku kata yang membantu anak dalam membaca permulaan yaitu dalam membaca tidak ada mengeja huruf demi huruf sehingga mempercepat proses penguasaan kemampuan membaca permulaan, dapat belajar mengenal huruf dengan mengupas atau menguraikan suku kata yang dipergunakan dalam unsur-unsur hurufnya, penyajian tidak memakan waktu yang lama, dapat secara mudah mengetahui berbagai macam kata Apriani, Cicilia (2013).

Terkait dengan penelitian membaca buku cerita dengan metode kupas rangkai suku kata ada beberapa penelitian metode kupas rangkai suku kata dengan objek kajian yang berbeda. Penelitian yang pertama adalah penelitian yang dilakukan oleh Cicilia Apriani (2013) Efektifitas Metode Kupas Rangkai Suku Kata Dalam Meningkatkan Kemampuan Membaca Permulaan Bagi Anak Kesulitan Membaca (Single Subject Research Kelas II di SDN 09 Pauh Padang ) yaitu untuk membuktikan apakah metode kupas rangkai suku kata efektif dalam meningkatkan kemampuan membaca permulaan bagi anak kesulitan membaca kelas II SDN 09 Pauh Padang. Penelitian yang kedua adalah penelitian yang dilakukan oleh Widya Nur Hidayah (2017) Metode Suku Kata Untuk Pembelajaran Membaca Permulaan Peserta Didik Low Vision yaitu untuk meningkatkan kemampuan membaca permulan pada aspek suku kata, lalu menjadi kata dan kalimat sederhana melalui metode suku kata. Berdasarkan dari kedua contoh penelitian tentang metode kupas rangkai suku kata dapat dikemukan bahwa penelitian ini berbeda dengan penelitian 
sebelumnya karena objek atau sumber data dalam penelitian ini adalah sebuah buku cerita anak untuk usia 3-4 tahun dengan fokus peneltian cara meningkatkan minat membaca buku cerita dengan metode kupas rangkai suku kata pada anak usia 3-4 tahun.

Meningkatkan minat membaca buku cerita dengan metode kupas rangkai suku kata pada anak usia 3-4 tahun di PAUD Ibu sadar Dusun nginjen Desa pandanpancur Kecamatan deket Kabupaten lamongan dipilih sebagai objek penelitian karena masih banyak ditemukan anak-anak pada usia 3-4 tahun tidak tertarik dengan buku cerita atau membaca buku cerita dan akhirnya penelitian ini dilakukan diawali dengan sebuah metode kupas rangkai suku kata untuk menarik dan mengajarkan anak-anak membaca buku cerita. Meningkatkan minat membaca buku cerita dengan metode kupas rangkai suku kata pada anak usia 3-4 tahun di PAUD Ibu sadar Dusun nginjen Desa pandanpancur Kecamatan deket Kabupaten lamongan belum pernah diteliti sehingga perlu dilakukan penelitian. Alasan peneliti memilih lokasi penelitian meningkatkan minat membaca buku cerita dengan metode kupas rangkai suku kata pada anak usia 3-4 tahun di PAUD Ibu sadar Dusun nginjen Desa pandanpancur Kecamatan deket Kabupaten lamongan karena ditemukan di lapangan atau di PAUD Ibu sadar anak-anak usia 3-4 tahun masih belum ada ketertarikan membaca buku cerita sehingga peneliti mencoba meneliti meningkatkan minat membaca anak-anak 3-4 tahun dalam metode kupas rangkai suku kata yang nantinya diharapkan anak-anak bisa dan lebih tertarik membaca buku cerita.

\section{TINJAUAN PUSTAKA}

Membaca merupakan suatu keterampilan berbahasa yang harus dimiliki oleh semua orang. Ada empat keterampilan dalam berbahasa yaitu: membaca, menyimak, menulis, dan berbicara. Membaca merupakan suatu kegiatan yang dilakukan oleh seorang pembaca untuk memperoleh suatu pesan yang akan disampaikan oleh pembaca melalui media lisan atau tulisan. Membaca merupakan memahami dari apa yang ditulis. Membaca adalah proses yang dilakukan serta dipergunakan oleh pembaca untuk memperoleh pesan, yang hendak disampaikan oleh penulis melalui media kata-kata atau bahasa tulis. Suatu proses yang menuntut agar kelompok kata yang merupakan suatu kesatuan akan terlihat dalam suatu pandangan sekilas dan makna kata-kata secara individual akan dapat diketahui. Kalau hal ini tidak terpenuhi, pesan yang tersurat dan yang tersirat tidak akan tertangkap atau dipahami, dan proses membaca itu tidak terlaksana dengan baik. (Hodgoson, 1960:43-44). Membaca di sekolah khususnya anak-anak usia 3-4 tahun biasanya diawali dengan tahap membaca permulaan misalnya membaca sebuah buku cerita anak. 
Tarigan (1995:5) mendefinisikan bahwa cerita anak adalah buku yang menempatkan mata anak-anak sebagai pengamat utama, mata anak-anak sebagai fokusnya. Bruno Bettheim (2011), menyebutkan bahwa cerita yang menarik untuk anak haruslah merangsang imajinasi, membantu mengembangkan kecerdasan, menjernihkan emosi, dan menyesuaikan diri dengan kecemasan ketika ia dihadapkan pada pencarian jalan keluar. Cerita untuk anak selayaknya berkaitan dengan anak, misalnya saja dongeng-dongeng yang merefleksikan pandangan anak tentang dunia. Pada anak usia 3-4 tahun metode yang digunakan membaca cerita anak salah satunya menggunakan sebuah metode kupas rangkai suku kata.

Metode kupas rangkai suku kata merupakan suatu metode yang memulai pengajaran dengan menyajikan dahulu beberapa suku kata. Suku kata dirangkaikan menjadi kata dengan menggunakan tanda sambung. Suku kata dikupas menjadi huruf-huruf. Huruf-huruf dirangkai kembali menjadi suku kata. Menurut Supriyadi Depdikbud (1992:12) metode kupas rangkai suku kata adalah suatu metode yang memulai pengajaran membaca permulaan dengan menyajikan kata-kata yang sudah di rangkai menjadi suku kata, kemudian suku-suku kata itu di rangkai, yang terakhir merangkai kata menjadi kalimat. Metode kupas rangkai suku kata yang membantu anak dalam membaca permulaan yaitu dalam membaca tidak ada mengeja huruf demi huruf sehingga mempercepat proses penguasaan kemampuan membaca permulaan, dapat belajar mengenal huruf dengan mengupas atau menguraikan suku kata yang dipergunakan dalam unsur-unsur hurufnya, penyajian tidak memakan waktu yang lama, dapat secara mudah mengetahui berbagai macam kata Apriani, Cicilia (2013).

Terkait dengan penelitian membaca buku cerita dengan metode kupas rangkai suku kata ada beberapa penelitian metode kupas rangkai suku kata dengan objek kajian yang berbeda. Penelitian yang pertama adalah penelitian yang dilakukan oleh Cicilia Apriani (2013) Efektifitas Metode Kupas Rangkai Suku Kata Dalam Meningkatkan Kemampuan Membaca Permulaan Bagi Anak Kesulitan Membaca (Single Subject Research Kelas II di SDN 09 Pauh Padang ) yaitu untuk membuktikan apakah metode kupas rangkai suku kata efektif dalam meningkatkan kemampuan membaca permulaan bagi anak kesulitan membaca kelas II SDN 09 Pauh Padang. Penelitian yang kedua adalah penelitian yang dilakukan oleh Widya Nur Hidayah (2017) Metode Suku Kata Untuk Pembelajaran Membaca Permulaan Peserta Didik Low Vision yaitu untuk meningkatkan kemampuan membaca permulan pada aspek suku kata, lalu menjadi kata dan kalimat sederhana melalui metode suku kata. Berdasarkan dari kedua contoh penelitian tentang metode kupas rangkai suku kata dapat dikemukan bahwa penelitian ini berbeda dengan penelitian sebelumnya karena objek atau sumber data dalam penelitian ini adalah sebuah buku cerita anak untuk usia 3-4 tahun dengan fokus peneltian cara meningkatkan minat membaca buku cerita dengan metode kupas rangkai suku kata pada anak usia 3-4 tahun. 
Meningkatkan minat membaca buku cerita dengan metode kupas rangkai suku kata pada anak usia 3-4 tahun di PAUD Ibu sadar Dusun nginjen Desa pandanpancur Kecamatan deket Kabupaten lamongan dipilih sebagai objek penelitian karena masih banyak ditemukan anak-anak pada usia 3-4 tahun tidak tertarik dengan buku cerita atau membaca buku cerita dan akhirnya penelitian ini dilakukan diawali dengan sebuah metode kupas rangkai suku kata untuk menarik dan mengajarkan anak-anak membaca buku cerita. Meningkatkan minat membaca buku cerita dengan metode kupas rangkai suku kata pada anak usia 3-4 tahun di PAUD Ibu sadar Dusun nginjen Desa pandanpancur Kecamatan deket Kabupaten lamongan belum pernah diteliti sehingga perlu dilakukan penelitian. Alasan peneliti memilih lokasi penelitian meningkatkan minat membaca buku cerita dengan metode kupas rangkai suku kata pada anak usia 3-4 tahun di PAUD Ibu sadar Dusun nginjen Desa pandanpancur Kecamatan deket Kabupaten lamongan karena ditemukan di lapangan atau di PAUD Ibu sadar anak-anak usia 3-4 tahun masih belum ada ketertarikan membaca buku cerita sehingga peneliti mencoba meneliti meningkatkan minat membaca anak-anak 3-4 tahun dalam metode kupas rangkai suku kata yang nantinya diharapkan anak-anak bisa dan lebih tertarik membaca buku cerita.

\section{METODE PENELITIAN}

\section{Rancangan Penelitian}

Penelitian tentang meningkatkan minat membaca buku cerita dengan metode kupas rangkai suku kata pada anak usia 3-4 tahun di PAUD Ibu sadar Dusun nginjen Desa pandanpancur Kecamatan deket Kabupaten lamongan menggunakan rancangan penelitian kualitatif. Rancangan penelitian kualitatif adalah suatu prosedur penelitian yang menghasilkan data-data deskriptif yang berupa kata tertulis atau lisan dari orang-orang dan perilaku yang dapat diamati. Penelitian kualitatif masih bersifat sementara, tentatif, dan akan berkembang atau berganti setelah peneliti berada di lapangan. Penelitian kualitatif akan terjadi tiga kemungkinan terhadap masalah yang dibawa peneliti dalam penelitian. Pertama, masalah yang dibawa oleh peneliti tetap, sehingga sejak awal sampai akhir penelitian sama. Kedua, masalah yang di bawa peneliti setelah memasuki penelitian berkembang yaitu memperluas atau memperdalam masalah yang telah disiapkan. Ketiga, masalah yang dibawa peneliti setelah memasuki lapangan berubah total (Sugiyono, 2011:205).

Berdasarkan uraian di atas dapat disimpulkan bahwa penelitian kualitatif adalah cara kerja dalam penelitian yang semata-mata mendeskripsikan keadaan objek berdasarkan fakta yang ada atau fenomena secara nyata nampak apa adanya. Mengacu pada definisi tersebut, dalam penelitian ini akan dijelaskan meningkatkan minat membaca buku cerita dengan metode kupas rangkai suku kata pada anak usia 
3-4 tahun di PAUD Ibu sadar Dusun nginjen Desa pandanpancur Kecamatan deket Kabupaten lamongan.

\section{Peran Peneliti}

Peran peneliti adalah sebagai alat pengumpul data dan instrumen kunci. Penelitian ini, peneliti merupakan alat pengumpul data utama. Peneliti sebagai instrumen utama dalam pengumpulan data, sebab sifatnya yang responsif, dan penganalisis karya sastra yang akan diteliti.

\section{Objek Penelitian}

Objek penelitian adalah variable penelitian yaitu sesuatu yang merupakan inti dari problematika penelitian (Arikunto, 2001:29). Objek utama penelitian ini adalah meningkatkan minat membaca buku cerita dengan metode kupas rangkai suku kata pada anak usia 3-4 tahun di PAUD Ibu sadar Dusun nginjen Desa pandanpancur Kecamatan deket Kabupaten lamongan.

Alasan memilih objek penelitian ini adalah karena anak usia 3-4 tahun di PAUD Ibu sadar tidak tertarik dengan membaca buku cerita anak sehingga peneliti ingin menerapkan penelitian ini dengan menggunakan metode kupas rangkai suku kata.

\section{Teknik Pengumpulan Data}

Penelitian ini teknik pengumpulan data yang digunakan adalah teknik observasi (participant observation), perekaman, dan pencatatan. Hal ini sesuai pendapat Sudikan (2001:173), teknik pengumpulan data pada sastra lisan dapat menggunakan (1) observasi, (2) perekaman, dan (3) pencatatan. Dengan teknik-teknik tersebut diharapkan dapat memperoleh data yang lebih akurat sesuai fokus penelitian. Teknik-teknik tersebut juga dapat dilakukan peneliti secara bersamaan dengan menyesuaikan kondisi di lapangan.

Teknik observasi digunakan untuk memperkuat data, terutama peninggalanpeninggalan yang masih tersimpan dan masih ada hubungannya dengan unsur budaya Lamongan. Melalui observasi alamiah data yang terkumpul akan semakin lengkap. Data yang diperoleh dari pengamatan secara alamiah akan lebih bermakna.

Teknik perekaman melalui camera digital (camdig) dan hp, teknik perekaman ini dilakukan untuk merekam dan mengamati kegiatan ritual ruwatan ontang anting. Data direkam dengan menggunakan camera digital dan hp. Teknik perekaman menurut Hutomo (dalam Firdaus, 2003:30) ada dua macam yaitu perekaman dalam bentuk asli (natural atau alamiah) dan perekaman tidak asli. Pada perekaman alamiah, cara ini disebut sebagai pendekatan etnografi yaitu perekaman dilakukan pada saat pertunjukan berlangsung. Sedangkan perekaman tidak asli 
adalah perekaman yang sengaja dilakukan. Pada penelitian ini perekaman dilakukan secara alamiah.

Teknik pengumpulan data selanjutnya yaitu pencatatan. Pencatatan digunakan untuk mencatat hal-hal yang berkaitan dengan rekaman, informasi, dan bahan (Hutomo, 1991:78). Dalam hubungannya dengan rekaman, catatan-catatan yang dibuat adalah menyangkut: tanggal rekaman, tempat rekaman, kegiatan, informan, dan penjelasan kata-kata atau istilah yang tidak dimengerti.

\section{Teknik Analisis Data}

Teknik analisis data yang digunakan adalah teknik analisis deskriptif. Teknik analisis deskriptif adalah teknik analisis data yang mendeskripsikan data apa adanya sehingga menimbulkan kejelasan dan kemudahan bagi pembaca Supratno (dalam Firdaus, 2003:37). Penelitian ini berusaha mendeskripsikan kenyataankenyataan yang ditemukan di lapangan, utamanya yang berhubungan dengan meningkatkan minat membaca buku cerita dengan metode kupas rangkai suku kata pada anak usia 3-4 tahun di PAUD Ibu sadar Dusun nginjen Desa pandanpancur Kecamatan deket Kabupaten lamongan.

Berikut ini adalah prosedur analisis data dilakukan dengan langkah-langkah sebagai berikut:

(1) Melakukan observasi di lapangan keadaan anak-anak usia 3-4 tahun di PAUD Ibu Sadar

(2) Melakukan sosialisasi kepada guru PAUD dan ibu-ibu wali murid yang mempunyai anak usia 3-4 tahun di PAUD Ibu Sadar

(3) Melakukan rekaman untuk melihat proses cara meningkatkan minat membaca buku cerita dengan metode kupas rangkai suku kata pada anak usia 3-4 tahun di PAUD Ibu sadar Dusun nginjen Desa pandanpancur Kecamatan deket Kabupaten lamongan

(4) Setelah data didapatkan dari hasil rekaman kemudian data diidentifikasi dan diklasifikasikan sesuai dengan fokus penelitian. Data yang telah diklasifikasikan dan siap di pakai selanjutnya diambil untuk disajikan dalam laporan analisis data.

(5) Data yang telah diklasifikasikan dan siap dipakai, selanjutnya dianalisis. Penganalisisan data dilakukan sesuai dengan fokus penelitian. Klasifikasi data dilakukan dengan menganalisis berdasarkan hasil observasi, perekaman, dan pencatatan. Peneliti juga mengkonsultasikan hasil penelitian kepada orang-orang yang memiliki otoritas dalam bidangnya. 


\section{TEMUAN DAN PEMBAHASAN}

Cara meningkatkan minat membaca buku cerita dengan metode kupas rangkai suku kata pada anak usia 3-4 tahun di PAUD Ibu sadar Dusun nginjen Desa pandanpancur Kecamatan deket Kabupaten lamongan yaitu :

1. Membaca buku cerita minimal sehari 2 kali

Sebagai guru PAUD Ibu sadar bisa memulai untuk membacakan buku cerita minimal 2 kali sehari setiap anak berada di sekolah. Hal tersebut sebagai reaksi anak untuk berimajinasi dengan cerita-cerita yang guru PAUD Ibu sadar bacakan. Sehari 2 kali dirasa cukup untuk anak membaca buku cerita dengan metode kupas rangkai kata karena semakin sering anak membaca dikhawatirkan anak semakin jenuh untuk belajar membaca cerita anak, dan semakin jarang anak membaca dikhawatirkan tidak ada ketertarikan dalam membaca dan bisa membuat anak lambat dalam membaca. Guru PAUD Ibu sadar membacakan cerita anak dengan menggunakan metode kupas rangkai suku kata karena anak usia 3-4 tahun masih belum bisa membaca dengan lancar dan dalam proses belajar membaca tahap permulaan. Buku yang dipilih adalah buku yang memuat hal-hal dunia anak maupun ilmu pengetahuan tentang anak tapi dalam penelitian ini buku yang dipilih adalah buku cerita anak karena dalam masa usia 3-4 tahun anak masih sering dan ingin mendengarkan sebuah cerita.

2. Memilih tema buku cerita yang disukai anak

Guru PAUD Ibu sadar memilihkan tema atau buku cerita yang disukai anak sehingga di sekolah harus mempunyai banyak koleksi buku cerita anakanak. Menyediakan bacaan buku cerita anak yang beragam untuk anak supaya tidak membuat anak cepat bosan. Sehingga guru PAUD Ibu sadar mencoba membuat perpustakaan mini di dalam sekolah untuk semakin menumbuhkan minat baca anak, dengan buku yang memiliki gambar dan berwarna yang bisa membantu anak untuk lebih senang melihat dan belajar membaca khususnya membaca cerita anak dengan metode kupas rangkai suku kata.

3. Mengatur waktu dalam membaca.

Guru PAUD Ibu sadar harus pintar dalam mengatur waktu dalam membacakan sebuah cerita anak dengan metode kupas rangkai suku kata karena anak PAUD Ibu sadar tergolong anak yang masih usia 3-4 tahun jadi anak ini masih sering mengalami kondisi yang berubah-ubah sesuai keinginan anak. Guru PAUD Ibu sadar menjadi salah satu sosok yang akan dicontoh oleh anak PAUD usia 3-4 tahun, contoh kecil yang dapat ditiru oleh anak adalah kebiasaan yang sering diterapkan oleh guru PAUD Ibu sadar dengan sering mengajak atau meluangkan waktu anak-anak untuk membaca buku cerita yang dapat membuat kebiasaan meluangkan waktu untuk 
membaca itu yang akan menjadikan sebuah kebiasaan yang baik untuk dicontoh oleh anak-anak PAUD Ibu sadar.

\section{KESIMPULAN DAN SARAN}

\section{Kesimpulan}

Berdasarkan hasil penelitian yang telah dipaparkan pada bab sebelumnya, dapat diisimpulkan bahwa meningkatkan minat membaca buku cerita dengan metode kupas rangkai suku kata pada anak usia 3-4 tahun di PAUD Ibu sadar Dusun nginjen Desa pandanpancur Kecamatan deket Kabupaten Lamongan, sebagai berikut:

1. Membaca buku cerita minimal sehari 2 kali setiap anak berada di sekolah PAUD Ibu sadar.

2. Memilih tema buku cerita yang disukai anak PAUD Ibu sadar dengan banyak menyediakan koleksi bahan bacaan buku cerita sehingga anak bisa memilih sendiri cerita yang dia sukai.

3. Mengatur waktu dalam membaca di sini guru PAUD Ibu sadar harus pintar dalam mengatur waktu dalam membacakan sebuah cerita anak dengan metode kupas rangkai suku kata karena anak PAUD Ibu sadar tergolong anak yang masih usia 3-4 tahun jadi anak ini masih sering mengalami kondisi yang berubah-ubah sesuai keinginan anak.

\section{Saran}

Hasil penelitian ini diharapkan dapat digunakan sebagai bahan pembelajaran bagi guru Paud untuk meningkatkan keterampilan membaca anak khusunya membaca buku cerita dan penelitian ini diharapkan dapat diteliti lebih lanjut dalam ruang lingkup yang lebih luas.

\section{DAFTAR PUSTAKA}

Anderson, Paul S. 1972. Language Skills in Elementary Education. New York:Macmillan Publishing Co. Inc.

Apriani, Cicilia.2013. EFEKTIFITAS METODE KUPAS RANGKAI SUKU KATA DALAM MENINGKATKAN KEMAMPUAN MEMBACA PERMULAAN BAGI ANAK KESULITAN MEMBACA (Single Subject Research Kelas II di SDN 09 Pauh Padang ). E-JUPEKhu (JURNAL ILMIAH PENDIDIKAN KHUSUS). Volume 2 Nomor 3 September 2013. http://ejournal.unp.ac.id/index.php/jupekhu. Diakses pada tanggal 25 Oktober 2020.

Arikunto,Suharsimi. 2006. Prosedur Penelitian Cetakan ke-13. Jakarta: Rineka Cipta. Arikunto. 1993. Prosedur Penelitian Suatu Pendekatan Praktek. Jakarta: Rineka Cipta. Finocchiaro, Mary and Bonomo Michael. 1973. The Foreign Language Learner: A guide for teacher. New York:Regents Publishing Company, Inc. 
Finocchiaro, Mary. 1964. Teaching Children Foreign Languages. New York: Mc GrawHill Book Company.

Finocchiaro, Mary. 1974. English as a Second Language. New York:Regents Publishing Company, Inc.

Hodgson, FM.1960. Learning Modern Languages. London Routledge \& Hegan Paul.

J. Moleong, Lexy. 2011. Metodologi Penelitian Kualitatif. Bandung: PT Remaja Rosdakarya.

Nur, Hidayah Widya.2017. Metode Suku Kata Untuk Pembelajaran Membaca Permulaan Peserta Didik Low Vision. JASSI_anakku. Volume 18 Nomor 2. Desember 2017. https://ejournal.upi.edu/index.php/jassi. Diakses pada tanggal 25 Oktober 2020. Sudikan, Setya Yuwana. 2001. Metode Penelitian Sastra Lisan.Surabaya: Citra Wacana. Sugiyono. 2010. Memahami Penelitian Kualitatif. Bandung: Alfabeta.

Supratno, Haris. 2008. Pendidikan dan Pelatihan Gurul PLPG 2008. Surabaya: Departemen Unesa.

Supriyadi, A. 1992. Rendemen Tebu : Liku-Liku Permasalahannya. Kanisius. Jakarta. Tarigan, Henry Guntur. 1978. Prinsip-prinsip Dasar Kritik Sastra. Bandung: FKSS IKIP. Tarigan, Henry Guntur. 1978a. Prinsip-prinsip Dasar Drama. Bandung: FKSS IKIP. Tarigan, Henry Guntur. 1978b. Prinsip-prinsip Dasar Fiksi. Bandung: FKSS IKIP. Tarigan, Henry Guntur.1977.Linguistik Kontrastif. Bandung:FKSS IKIP. Witakania. 2008. Aspek Psikopedagogik dalam Sastra Anak. Bandung: Angkasa. 